\title{
Eleutherinone, a Novel Fungitoxic Naphthoquinone from Eleutherine bulbosa (Iridaceae)
}

\begin{abstract}
Tânia Maria Almeida Alves, Helmut Kloos*, Carlos Leomar Zani/ ${ }^{+}$
Laboratório de Química de Produtos Naturais, Centro de Pesquisas René Rachou-Fiocruz, Av. Augusto de Lima 1715, 30190-002 Belo Horizonte, MG, Brasil *Department of Epidemiology and Biostatistics, University of California, San Francisco Medical

Center, San Francisco, CA, US

The dichloromethane extract prepared from the underground parts of Eleutherine bulbosa (Miller) Urban (Iridaceae) showed strong activity in the direct bioautography assay with the phytopathogenic fungus Cladosporium sphaerospermum. This assay was used to guide the fractionation of this extract and allowed the isolation of four compounds: the new naphthoquinone eleutherinone [8-methoxy-1-methyl-1,3-dihydro-naphtho(2,3-c)furan-4,9dione] and the known compounds, previously isolated from this species, eleutherin [9-methoxy-1(R),3(S)-dimethyl3,4-dihydro-1H-benzo(g)isochromene-5,10-dione], isoeleutherin [9-methoxy-1(R),3(R)-dimethyl-3,4-dihydro-1Hbenzo(g)isochromene-5,10-dione], and eleutherol [4-hydroxy-5-methoxy-3(R)-methyl-3H-naphtho(2,3-c)furan-1one]. All quinonoid compounds showed strong antifungal activity in the bioautography assay at $100 \mu \mathrm{g} / \mathrm{spot}$, while eleutherol was inactive.
\end{abstract}

Key words: naphthoquinone - Eleutherine bulbosa - fungicide - medicinal plant - Cladosporium sphaerospermum

Eleutherine bulbosa (Miller) Urban is an herb from Iridaceae, a botanical family that comprises 90 genera and about 1200 species (Schultes \& Raffauf 1990). This plant is used by some populations as a vermifuge (Schultes \& Raffauf 1990), for painful and irregular menstruation (Hodge \& Taylor 1956), intestinal disorders (Van den Berg 1984, Lin et al. 2002) and as an abortive and antifertility agent (Weniger et al. 1982). In the state of Minas Gerais, some populations near the "Rio Doce" valley make infusions of the underground bulbs of this plant to treat intestinal infections (Kloos, unpublished data). Eleutherine americana Merr. ex K. Heyne is a related herb and its rhizome is used as a folk medicine for the treatment of coronary disorders (Ding \& Huang 1983). The rhizomes of Eleutherine subaphylla Gagnep. are used as haemostatic and antibacterial agents (Dam \& Mai 1990). Several compounds, including elecanicin, eleutherol, isoeleutherol, eleutherin, isoeleutherin (Hara et al. 1997), hongconin (Zhengxiong et al. 1984) as well as anthraquinones (Komura et al. 1983) and their glycosides (Shibuya et al. 1997) have already been isolated and identified from bulbs of plants belonging to this genus. Some compounds present in the genus display important biological activities. Thus, Hara et al. (1997) described eleutherin as forming a type of "noncleavable complex" with topoisomerase II with stereospecific and selective inhibitory activity. These authors also described the inhibitory activity of isoeleutherin and isoeleutherol against HIV replication in H9 lymphocytes.

\footnotetext{
Sponsorship Fiocruz/CNPq/Pronex

${ }^{+}$Corresponding author. Fax: +55-31-3295.3115. E-mail: zani@cpqrr.fiocruz.br

Received 20 December 2002

Accepted May 2003
}

The direct bioautographic assay is a rapid and sensitive method to detect fungitoxic compounds (Homans \& Fuchs 1977). The use of this assay with Cladosporium sphaerospermum was demonstrated by the detection and isolation of antifungal amides from Piper arboreum (Silva et al. 1998) and polygodial from Polygonum punctatum (Alves et al. 2001). This fungus is pathogenic to plants such as Lutjanus campechanus (Blaylock et al. 2001) and other organisms including the invertebrate marine species Hippodiplosia insculpta (Sterflinger et al. 2001). With the aim of detecting bioactive natural products we evaluated hundreds of plant extracts using this assay. As a result the fungitoxic activity of the dichloromethane extract from bulbs of E. bulbosa was detected. Although previous study showed the presence of the xanthones mangiferin and isomangiferin in the leaves of E. bulbosa (Williams \& Harborne 1985) no report on the chemical investigation of its bulbs could be found. We report herein the isolation and identification of the fungitoxic components of the bulbs of this plant extract by a bioassayguided chemical fractionation protocol.

\section{MATERIALS AND METHODS}

The bulbs (170 g) of E. bulbosa were collected on February 1998 at Nova União (municipality of Itabirinha de Mantena), state of Minas Gerais, Brazil. A voucher specimen was deposited at the Federal University of Minas Gerais Herbarium, under the code BHCB 41473.

The plant material was oven-dried at $45^{\circ} \mathrm{C}$, crushed, and macerated $(3 \times 24 \mathrm{~h})$ with dichloromethane to produce $2.5 \mathrm{~g}$ of crude extract. This extract was fractionated on a MPLC column ( 490 X $50 \mathrm{~mm}$ ) of silica gel (230-400 mesh) at a flow rate of $60 \mathrm{ml} / \mathrm{min}$ using a step gradient of hexaneethyl acetate $25 \%$ (35 $\mathrm{min}) ; 50 \%$ (15 $\mathrm{min}) ; 75 \%$ (25 $\mathrm{min})$ and $100 \%$ (10 min). Nineteen fractions $(270 \mathrm{ml})$ were collected and the solvents removed in a rotary evaporator under vacuum, at temperatures under $45^{\circ} \mathrm{C}$. Fraction 11 (Rt $51 \mathrm{~min} ; 110 \mathrm{mg}$ ) was subjected to a semi-preparative 
HPLC separation on a DIOL column $(20 \times 250 \mathrm{~mm}, 7 \mu \mathrm{m}$ particle size) using a mixture of hexane-dichloromethaneacetonitrile (187:7:6) at $10 \mathrm{ml} / \mathrm{min}$ to yield $5 \mathrm{mg}$ of eleutherinone (1). Under similar conditions, the fraction 10 (Rt $45 \mathrm{~min} ; 78 \mathrm{mg}$ ) was eluted with a mixture of hexanedichloromethane-acetonitrile (79:19:2) and yielded 2 (eleutherol, $29 \mathrm{mg}$ ), 3 (eleutherin, $4.7 \mathrm{mg}$ ), and 4 (isoeleutherin, $12 \mathrm{mg}$ ) (Fig. 1).

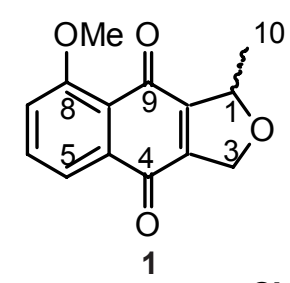

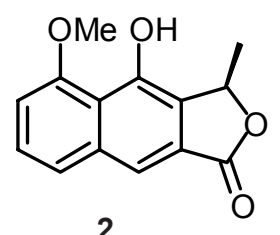

2

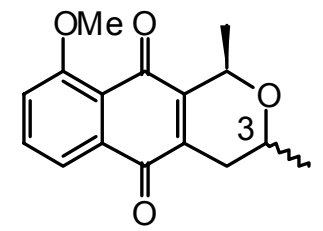

3, 3-S

$4,3-R$
Fig.1: 1: eleutherinone; 2: eleutherol; 3: eleutherin; 4: isoeleutherin

Compound 1 crystallized from ethanol as yellow needles with $\mathrm{mp} 156-158^{\circ} \mathrm{C} ;[\alpha]^{25}{ }_{\mathrm{D}}+60\left(\mathrm{c} 0.13, \mathrm{CH}_{2} \mathrm{Cl}_{2}\right)$; $\mathrm{UV}\left(\mathrm{CH}_{3} \mathrm{OH}\right) \lambda_{\max }(\log \varepsilon) 228(4.29) ; 242(4.26) ; 288(3.64)$; 330 (3.52); 347 (3.46) and $400(3.57) ;{ }^{1} \mathrm{H} \mathrm{NMR}\left(\mathrm{CDCl}_{3}\right.$, $400 \mathrm{MHz})$ and ${ }^{13} \mathrm{C}$ NMR $\left(\mathrm{CDCl}_{3}, 100 \mathrm{MHz}\right)$ : see Table. EIMS $m / z$ (\% intensity): $244[\mathrm{M}]^{+}(79), 229[\mathrm{M}]^{+}-\mathrm{Me}(100)$, $202(20), 201[\mathrm{M}]^{+}-\mathrm{Me}-\mathrm{CO}(14), 173[\mathrm{M}]^{+}-\mathrm{Me}-2 \times \mathrm{CO}$ (15), $143(10), 127(10), 115$ (40), $102(11), 76(37)$.

The spectral and physical properties of 2,3 , and 4 were identical to those published in the literature (Hara et al. 1997).

Antifungal activity - The bioautographic assay with the spores of $C$. sphaerospermum was run using the procedure developed by Homans and Fuchs (1977). Briefly, the extract, fractions and pure compounds were dissolved in a volatile solvent and spotted $(100 \mu \mathrm{g})$ on commercial silica gel TLC plates $(20 \times 20 \mathrm{~cm}, 200 \mu \mathrm{m}$ layer thickness, with fluorescent indicator). A suspension of the fungal spores $\left(10^{6} / \mathrm{ml}\right)$ in a nutrient medium (glucose and salts) was sprayed over the plates which were then incubated in a humid atmosphere for three days in the dark, at room temperature. The presence of fungitoxic substances was detected by the appearance of an inhibition zone. Thymol $(50 \mu \mathrm{g} / \mathrm{spot})$ and solvent $(10 \mu \mathrm{l})$ were used as controls.

\section{DISCUSSION}

The oven-dried bulbs were crushed and macerated with dichloromethane to afford an extract that showed strong growth inhibition in the bioautographic assay using the fungus $C$. sphaerospermum. Medium pressure column chromatography over silica gel using mixtures of hexane-ethyl acetate as eluents yielded two active fractions that were further purified by HPLC on a DIOL col- umn to afford four compounds. Three of them, $\mathbf{2 , 3}$, and $\mathbf{4}$, were identified by comparison of their physical and spectral data with those published in the literature (Hara et al. 1997). Compound 1 was found to be new and its structural elucidation is described bellow. The pure compounds were subjected to the bioautographic assay with the spores of C. sphaerospermum at $100 \mu \mathrm{g} / \mathrm{spot}$. Only the quinonoid compounds $(\mathbf{1}, \mathbf{3}$ and 4$)$ were active, producing clear growth inhibition zones.

Compound 1 showed molecular ion peak with $\mathrm{m} / \mathrm{z}$ 244,0728 daltons in the high resolution mass spectrum (Calcd. for $\mathrm{C}_{14} \mathrm{H}_{12} \mathrm{O}_{4}=244.0736$ daltons). The calculated molecular formula is consistent with the ${ }^{1} \mathrm{H}$ NMR and ${ }^{13} \mathrm{C}$ NMR spectra, from which signals due to 14 carbons and integration of 12 hydrogen atoms were evident (Table). Furthermore, signals from four methyne, one methylene and two methyl groups could be distinguished in the DEPT sub-spectrum, thus corroborating the number of hydrogen atoms in the molecule. The ${ }^{13} \mathrm{C}$ NMR spectrum showed signals relative to two carbonyls $(\delta 181.90$ and $\delta$ $181.31)$ and to an aromatic methoxy group ( $\delta 56.52)$, accounting for three of the four oxygen atoms. The chemical shifts of a methyne at $\delta 82.04$ and of a methylene at $\delta$ 71.47 indicate that they are connected to an oxygen atom in an ether group. One of the substituents of the methyne is a methyl group, as deduced by the couplings observed in the ${ }^{1} \mathrm{H}$ NMR and COSY spectra, compatible with the substructure shown in Fig. 2a.

The UV absorption spectrum of $\mathbf{1}$ indicates the presence of a substituted naphthoquinone chromophore with $\lambda_{\text {max }}$ at 228, 242, 288, 330, 347 and $400 \mathrm{~nm}$. Furthermore, besides the two close carbonyl signals mentioned above, the ${ }^{13} \mathrm{C}$ NMR spectrum presents eight signals in the region between $\delta 165$ and $\delta 115$ that are compatible with a substituted $p$-naphthoquinone ring system (Fig. 2b). The ${ }^{1} \mathrm{H}$ NMR spectrum showed signals due to three vicinal aromatic protons at $\delta 7.76(1 \mathrm{H}$, dd $J=1.2,7.6), 7.69(1 \mathrm{H}$, dd $J=8.4,7.6)$ and $7.28(1 \mathrm{H}, \mathrm{dd} J=1.2,8.4)$ and to one aromatic methoxy group at $\delta 4.02$ (Table). These data are compatible with a 5-methoxy-1,4-naphthoquinone substructure (Fig. 2b). All structural features described so far account for eight of the nine insaturations predicted by the molecular formula. As all $\mathrm{sp}^{2}$ carbons were already allocated, the last insaturation must be due to a third ring based on the ether fragment deduced above. The connection of these fragments forms a 1,3-dihydro-naphtho(2,3c) furan-4,9-dione ring system in which the quinonoid double bond between the methyne and the methylene of the furanoid ring could explain the long range coupling between them observed in the ${ }^{1} \mathrm{H}$ NMR and COSY experi-<smiles>CCOC(C)C</smiles>

a<smiles>COc1ccc2c(c1)C(=O)C(C)=C(C)C2=O</smiles>

b
Fig. 2: partial structures of eleutherine deduced from spectral data. 
TABLE

NMR data of eleutherinone in $\mathrm{CDCl}_{3}\left(400 \mathrm{MHz}\right.$ for ${ }^{1} \mathrm{H}$ and $100 \mathrm{MHz}$ for ${ }^{13} \mathrm{C}$ )

\begin{tabular}{|c|c|c|c|c|c|c|}
\hline $\mathrm{C}$ & $\delta_{\mathrm{C}}\left(\mathrm{CDCl}_{3}\right)$ & DEPT & HMQC & $\delta_{\mathrm{H}}\left(\mathrm{CDCl}_{3}\right)$ & COSY & HMBC \\
\hline $4^{a}$ & 181.86 & $\mathrm{C}$ & \multirow{8}{*}{$\mathrm{H}_{6}$} & - & - & \multirow{7}{*}{$\begin{array}{c}\mathrm{H}_{6} \\
\mathrm{H}_{3 \mathrm{a}} ; \mathrm{H}_{3 \mathrm{~b}} ; \mathrm{H}_{10} \\
\mathrm{H}_{3 \mathrm{a}} ; \mathrm{H}_{3 \mathrm{~b}} \\
\mathrm{H}_{6}\end{array}$} \\
\hline $9^{a}$ & 181.31 & $\mathrm{C}$ & & - & - & \\
\hline 8 & 160.16 & $\mathrm{C}$ & & - & - & \\
\hline $9^{a}$ & 150.52 & $\mathrm{C}$ & & - & - & \\
\hline $3^{a}$ & 143.60 & $\mathrm{C}$ & & - & - & \\
\hline $4^{a}$ & 135.35 & $\mathrm{C}$ & & - & - & \\
\hline 6 & 135.05 & $\mathrm{CH}$ & & $7.69(\mathrm{dd}, J=8.4,7.6)$ & $\mathrm{H}_{5} ; \mathrm{H}_{7}$ & \\
\hline $8^{a}$ & 120.46 & $\mathrm{C}$ & & - & - & \multirow{3}{*}{$\begin{array}{c}\mathrm{H}_{5} ; \mathrm{H}_{7} \\
\mathrm{H}_{7}\end{array}$} \\
\hline 5 & 119.21 & $\mathrm{CH}$ & $\mathrm{H}_{5}$ & $7.76(\mathrm{dd}, J=7.6,1.2)$ & $\mathrm{H}_{6} ; \mathrm{H}_{7}$ & \\
\hline 7 & 118.38 & $\mathrm{CH}$ & $\mathrm{H}_{7}$ & $7.33(\mathrm{dd}, J=8.4,1.2)$ & $\mathrm{H}_{5} ; \mathrm{H}_{6}$ & \\
\hline 1 & 82.04 & $\mathrm{CH}$ & $\mathrm{H}_{1}^{\prime}$ & $5.42(\mathrm{ddq}, J=6.8,5.8,3.8)$ & $\mathrm{H}_{10} ; \mathrm{H}_{3 \mathrm{a}} ; \mathrm{H}_{3 \mathrm{~b}}$ & \multirow{3}{*}{$\begin{array}{c}\mathrm{H}_{5} \\
\mathrm{H}_{10}\end{array}$} \\
\hline 3 & 71.47 & $\mathrm{CH}_{2}$ & $\mathrm{H}_{3 \mathrm{a}}$ & $5.12(\mathrm{dd}, J=16,5.8)$ & $\mathrm{H}_{3 b} ; \mathrm{H}_{1}$ & \\
\hline & & & $\mathrm{H}_{3 \mathrm{~b}}^{3 \mathrm{a}}$ & $5.00(\mathrm{dd}, J=16,3.8)$ & $\mathrm{H}_{3 \mathrm{a}} ; \mathrm{H}_{1}$ & \\
\hline 11 & 56.52 & $\mathrm{CH}_{3}$ & $\mathrm{H}_{11}$ & $4.02(\mathrm{~s})$ & - & \multirow[b]{2}{*}{$\mathrm{H}_{3 \mathrm{a}} ; \mathrm{H}_{3 \mathrm{~b}}($ weak $)$} \\
\hline 10 & 20.66 & $\mathrm{CH}_{3}$ & $\mathrm{H}_{10}$ & $1.57(\mathrm{~d}, J=6.8)$ & $\mathrm{H}_{1}$ & \\
\hline
\end{tabular}

$a$ : these attributions may be interchanged.

ments. Finally, as the NOESY experiment shows the nuclear Overhouser effect between the methyl and methoxy groups, they were located on the same side of the structure. This analysis leads to structure (Fig. 1), corresponding to 8-methoxy-1-methyl-1,3-dihydro-naphtho(2,3c) furan-4,9-dione.

Although the isolated natural product is optically active $\left([\alpha]^{25} \mathrm{D}+60^{\circ}\right)$, the stereochemistry at $\mathrm{C}-1$ could not be with the available spectral data. However, the accessibility of $\mathbf{2}$, for which the stereochemistry was unequivocally determined by comparison with literature data, offers the possibility to define the stereochemistry of $\mathbf{1}$ via chemical transformations. Thus, we anticipate that the the lactone carbonyl of the naphthofuran 2 could be reduced and the resulting phenol oxidized to one of the two possible enantiomers of $\mathbf{1}$. Comparison of the optical rotation and other physicochemical data would afford the correct stereochemistry of $\mathbf{1}$. The results of this investigation will be described in a forthcoming communication.

Even though several plants of this genus had already been investigated, the use of a simple bioassay was able to guide the chemical fractionation to a new bioactive naphthoquinone. Thus, besides contributing to the knowledge of the chemical composition of this species, the new quinone 1 could be useful as a chemical marker (Williams $\&$ Harborne 1985) of this species/genus in chemosystematic studies, for extract standardization, and plant drug analysis. Further studies on this species aiming at minor components as well detailed investigation on the biological activities of the isolated compounds are now in progress and will be reported elsewhere.

\section{ACKNOWLEDGEMENTS}

To Dr L Capellari Jr. for the plant determination, Dr Lúcia PS Pimenta and Dr Marcos Eberlin for the optical activity and HRMS measurements, and Ms Mary Lou Quinn for the access to the Napralert database.

\section{REFERENCES}

Alves TMA, Ribeiro FL, Kloos H, Zani CL 2001. Polygodial, a fungitoxic sesquiterpene from Polygonum punctatum. Mem Inst Oswaldo Cruz 96: 831-833.

Blaylock RB, Overstreet RM, Klich MA 2001. Mycoses in red snapper (Lutjanus campechanus) caused by two deuteromycete fungi (Penicillium corylophilum and Cladosporium sphaerospermum). Hydrobiologia 460: 221-228.

Dam DT, Mai PD, 1990. Medicinal Plants in Viet Nam, WHO, Institute of Materia Medica Hanoi, Manila, p.166-167.

Ding J, Huang H 1983. Extraction of water-soluble active fraction of Hongcong (Eleutherine americana) and preparation of the injection. Chung Ts' Ao Yao 14: 351-352.

Hara H, Maruyama N, Yamashita S, Hayashi Y, Lee KH, Bastow KF, Chairul RM, Imakura Y 1997. Elecanacin, a novel new naphthoquinone from the bulb of Eleutherine americana. Chem Pharm Bull 45: 1714-1716.

Hodge WH, Taylor D 1956. The ethnobotany of the island Caribs of Dominica. Webbia 12: 513-644.

Homans AL, Fuchs A 1970. Direct bioautography on thinlayer chromatograms as a method for detecting fungitoxic substances. J Chromatogr 51: 327-329.

Komura H, Mizukawa K, Minakata H, Huang H, Qin G, Xu R 1983. New anthraquinones from Eleutherine americana. Chem Pharm Bull 31: 4206-4208.

Lin J, Puckree T, Mvelase TP 2002. Anti-diarrhoeal evaluation of some medicinal plants used by zulu traditional healers. J Ethnopahrmacol 79: 53-56.

Schultes RE, Raffauf RF 1990. The Healing Forest. Medicinal and Toxic Plants of the Northwest Amazonia, Dioscorides Press, Portland, US, p. 218-219.

Shibuya H, Fukushima T, Ohashi K, Nakamura A, Riswan S, Kitagawa I 1997. Indonesian medicinal plants. 20. Chemical structures of eleuthosides A, B, and C, three new aromatic glucosides from the bulbs of Eleutherine palmifolia (Iridaceae). Chem Pharm Bull 45: 1130-1134.

Silva JRD, Rezende CM, Pinto AC, Pinheiro MLB, Cordeiro MC, Tamborini E, Young CM, Bolzani VD 1998. Triterpenic ester from Himatanthus sucuuba (Spruce) Woodson. Quimica Nova 21: 702-704. 
Sterflinger K, Hain M, Scholz J, Wasson K 2001. Fungal infections of a colonial marine invertebrate: diversity and morphological consequences. Facies 45: 31-37.

Van den Berg MA 1984. Ver-o-peso: the ethnobotany of an Amazonian market. In Prance \& Kallunk, Advances in Economic Botany. Ethnobotany in the Neo Tropics, New York Botanical Garden, New York, p. 140-149.

Weniger B, Haag-Berrurier M, Anton R 1982. Plants of Haiti used as antifertility agents. J Ethnopharmacol 6: 67-84.

Williams CA, Harborne JB 1985. Biflavonoids, quinones and xanthones as rare chemical markers in the family Iridaceae. Z Naturforsch Ser C 40: 325-330.

Zhengxiong C, Huizhu H, Chengruui W, Yuhui L, Jianmi D, Sankawa U, Noguchi H, Iitaka Y 1984. Hongconin, a new naphthalene derivative from the rhizome of Eleutherine americana (Hong-Cong). Heterocylces 22: 691-694. 